\title{
Influence of product innovation and influencer marketing on the interest in buying Bluebutton fashion products
}

\author{
Randy Arvin Claudio ${ }^{\mathbf{1}}$, Didi Tarmidi ${ }^{\mathbf{2}}$ \\ Faculty of Economy and Business, University of Widyatama, Bandung-Indonesia \\ randy.arvin@widyatama.ac.id ${ }^{1}$,didi.tarmidi@widyatama.ac.id ${ }^{2}$
}

\begin{abstract}
Analysis to examine thanks to describe product innovation, influencer selling, and buying interests, additionally on confirm but the influence product innovation and influencer selling on the interest in shopping for fashion merchandise in Bluebutton. The factors tested inside the study were product innovation and influencer marketing as freelance variables, whereas buying interests were dependent variables. The analysis methods. employed in this research are descriptive and verification methods. The analysis ways used in.this research.are descriptive and verification methods. The population throughout this study was the one who knew bluebutton fashion products. The sampling technique used within the study was nonprobability sampling and additionally the scale of the sample within the study was calculated by Bernoulli' formula, that the whole vary was one hundred respondents. The analytical ways employed in this study are some regression analyses victimization SPSS25 Windows. The results this study show that product innovation and influencer marketing have an impression on the interest in buying Bluebutton fashion products. The magnitude of the influence of product innovation.and influencer marketing on buying interest by $40.4 \%$.
\end{abstract}

Keywords: Product Innovation; Influencer Marketing; Buy Interests

\section{Introduction}

Fashion is the way of life of a particular community and is part of social life. Some experts argue that fashion is a purchase that requires high consumer engagement. This strong involvement of consumers in the selection of clothing products pays more detailed attention to various aspects of clothing evaluation. Cardoso (2017) stated that in the selection of fashion products, consumers tend to pay attention to various aspects related to value, media and seller position. 
Purchase interest plays a very important role. Buying interest is the stage where consumers evaluate the information received. One way to get consumers interested in the products on offer is to develop new products and use influencers.

The increasing intensity of competition between makers forces firms forever concentrate to fashion trends in step with clients' needs and check out to satisfy consumer expectations by springing up with new fashion innovations, to vie with alternative businesses victimization methods the key to business success failure.

An influencer is someone whose words can influence others. Influencers are not a celebrity, but ordinary people can also be said to be influencers if the person has a lot of followers and their words can influence others. One of the reasons that influencers are used by businesses to increase awareness and purchase interest.

\section{Frame of mind}

A framework thought could be a abstract model of however theory is combined with a spread of things that are known as necessary issues. an honest frame of mind would on paper explain the interrelationships between the variables studied. thus it's theoretically necessary to elucidate the link between freelance and dependent variables.

Creative innovation sports whether or not system innovation or services or products innovation will enhance the company's capacity to create fine merchandise, similarly predicted to boom the company's aggressive gain which in the long run has an effect at the company's performance. According to Robbins \& Coulter (2017), innovation itself is described as taking innovative thoughts and turning them into beneficial merchandise or running methods. A commercial enterprise that could make innovation then the commercial enterprise can lead and reduce the opportunity of competition innovating early. Lukas and Ferrell (2018) defined the life of numerous evaluation signs of product innovation, namely: (1) Product Expansion (line extensions), (2) Product Impersonation (me-too merchandise), and (3) New-to-the-global merchandise).

Influencer promoting may be a new marketing approach, necessary as a result of sales are forced to grasp and support it. It directly addresses the foremost common sales barriers in potential customers and focuses attention on the folks that advise decision-makers. in line with Omayma Al Farraj, et.al, (2020) indicators concerning influencer marketing are (1) Attractiveness, (2) Trustworthiness, and (3) Expertise.

According to Priansa (2017: 164) states that buying interest is a consumer behavior that arises in response to objects that indicate a person's desire to buy. Real needs and desires are not easy to know. According to Schiffman and Kanuk (2018) indicators regarding buying interest are (1) Interested in finding information about the product, (2) Want to know the product, (3) Interested in trying, (4) Consider buying, and (5) Want to have a product. 


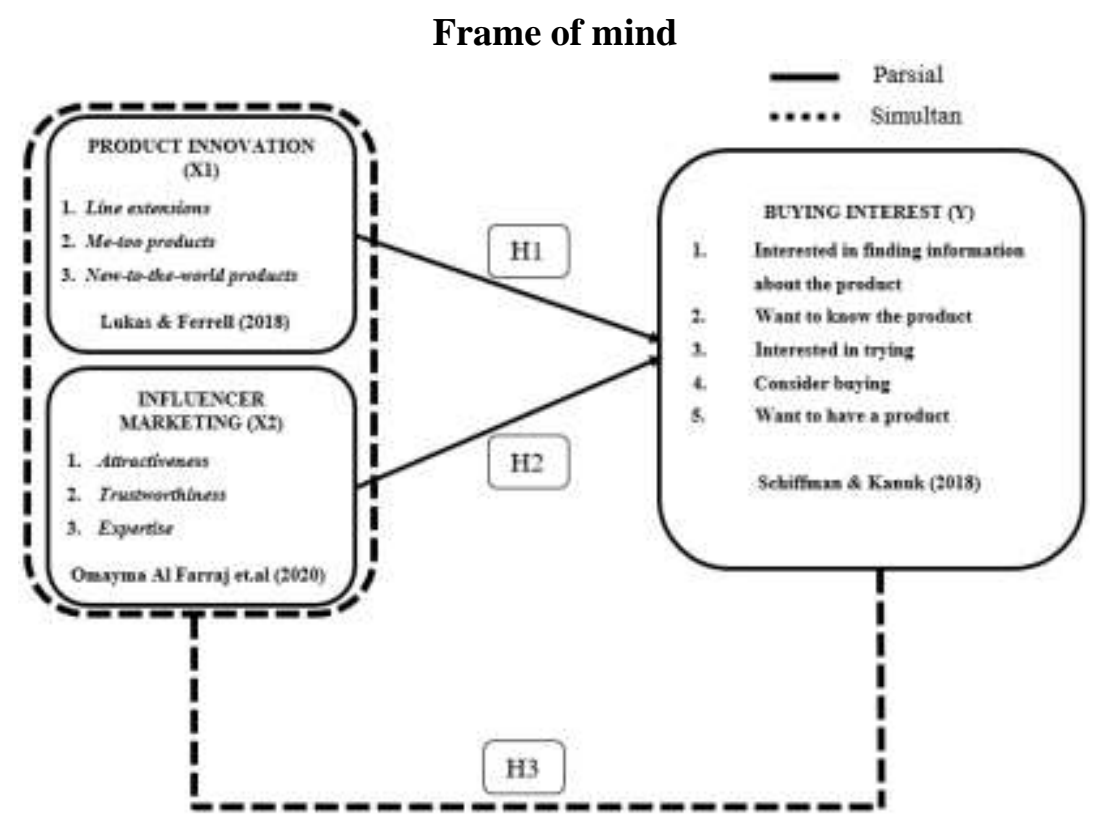

From the higher than frame of mind, it are often known, that the independent variables are Product Innovation (X1) and Influencer marketing (X2), whereas the variable is buying Interest $(\mathrm{Y})$.

The hypotheses planned during this study are as follows:

H1: It suspected that there's a partial influence between product innovation (XI) on buying interest $(Y)$.

H2: It suspected that there is a partial influence between influencer marketing (X2) on buying interest $(Y)$.

H3: It suspected that there is associate influence between product innovation (X1) and influencer marketing (X2) at the same time on buying interest $(Y)$.

\section{Research methods}

\section{Kinds of analysis}

The study can use descriptive quantitative approach to clarify the result of product innovation and influencer promoting variables on the acquisition of variables of interest with multiple regression processes and treated victimisation SPSS twenty five for Windows applications. The non-probability sampling technique may be a sampling technique that doesn't provide an equivalent chance for every component or member of the population to be elect from a sample. The study sample size was calculated using Bernoulli' formula, and so the calculation of the whole sample obsessed to one hundred respondents was asked to complete a search form. every sampled individual are going to be asked to complete a questionnaire according.to the Linkert scale with a scale of 1-5 (strongly disagree - powerfully agree) to work out the extent of influence of the merchandise innovation variables, multi-row regression (X1) and influencer promoting (X2) techniques are used on the acquisition interest variable (Y) . 


\section{Results and discussions \\ Multiple correlation analysis}

The aim of multivariate analysis is confirm the present relationships between variables in order that one variable is calculable from the recorded relationships if another variable is known. The regression model equation employed by the author could be a double regression analysis equation. A model regression of $\mathrm{y}$ on $\mathrm{x}$ supported varied statistical regression analyzes is bestowed below, as follows:

Multiple linear regression table

\begin{tabular}{|c|c|c|c|c|c|c|}
\hline & \multirow{2}{*}{ Model } & \multicolumn{2}{|c|}{$\begin{array}{c}\text { Unstandardized } \\
\text { Coefficients }\end{array}$} & $\begin{array}{l}\text { Standardized } \\
\text { Coefficients }\end{array}$ & \multirow{2}{*}{$\mathrm{t}$} & \multirow{2}{*}{ Sig. } \\
\hline & & B & Std. Error & Beta & & \\
\hline \multirow[t]{3}{*}{1} & (Constant) & 3.021 & 2.435 & & 1.241 & .218 \\
\hline & $\mathrm{X} 1$ & .110 & .136 & .085 & .811 & .420 \\
\hline & $\mathrm{X} 2$ & .617 & .113 & .575 & 5.457 & .000 \\
\hline
\end{tabular}

The result of the calculation is the constant value (a) of 3.021, the product innovation value (X1) of 0.110 and the influencer marketing value (X2) of 0.617 . The formula of the regression equation is as follows:

$$
Y=3,021+0,110 X_{1}+0,617 X_{2}+e
$$

1. If the consistent price of 3.021 manner that if the impartial variable this is the product innovation variable and influencer advertising are taken into consideration consistent (really well worth 0 ), then the structured variable i.e. the purchase hobby variable may be really well worth 3,021 . That is, whilst there may be no alternate withinside the price of product innovation and influencer advertising, then the price does now no longer alternate.

2. If the regression coefficient price of the product innovation variable suggests 0.110 , that means that if the product innovation variable will increase with the aid of using (one) unit, even as the alternative impartial variable this is the influencer advertising variable is taken into consideration consistent (really well worth 0 ), then the structured variable this is numerous shopping for hobby will growth with the aid of using 0.110 . Positive symptoms and symptoms at the regression price coefficient suggest that product innovation has a wonderful have an impact on on shopping for hobby. This manner that the better the product innovation, the better the customer's shopping for hobby.

3. If the regression coefficient price of influencer advertising variable suggests 0.617 , that means that if the influencer advertising variable will increase with the aid of using (one) unit, even as the alternative impartial variable this is the product innovation variable is taken into consideration consistent (really well worth 0 ), then the structured variable this is the variable of purchasing hobby will growth with the aid of using 0.617 . Positive symptoms and symptoms at the regression price coefficient suggest that influencer advertising has a wonderful have an impact on on a customer's shopping for hobby. This manner that the better the price of influencer advertising, the better the shopping for hobby of customers. 


\section{Simultaneous Table Hypothesis Test}

The compliance take a look at (F test) uses the F statistical test with the search pattern $\mathrm{Y}$ $=\beta 1 X 1+\beta 2 X 2+e$. The $F$ test result got the $F$ count at 32,915 with a significance level of 0.000 . Since the importance worth obtained is 0.000 elt; 0.05 , it are often over that this study glad the F test with its F value bigger than 32.915 compared to Table F 3.090.

Test coefficient of determination table

\begin{tabular}{ll|r|r|r} 
& \multicolumn{4}{c}{ Model Summary } \\
Model & $\mathrm{R}$ & $\mathrm{R}$ Square & Adjusted R Square & Std. Error of the Estimate \\
\hline 1 & $.636^{\mathrm{a}}$ & .404 & .392 & 2.24204 \\
\hline
\end{tabular}

a. Predictors: (Constant), TOTAL_X2, TOTAL_X1

b. Dependent Variable: TOTAL_Y

Based on the.results of the Kuefisiensi Determination. Test obtained a price of $\mathrm{R}$ sq of 0.404 , this implies that there's a control of $40.4 \%$ of product innovation variables (X1) and influencer marketing variables (X2) on shopping for interest variables (Y), and an effect of 59.6\% by other variables not studied in this study.

Descriptive analysis

Product innovation in Bluebutton

The results showed that in the product innovation variable (X1) obtained the value of the

\begin{tabular}{|c|c|c|c|c|c|c|}
\hline & Model & $\begin{array}{l}\text { Sum of } \\
\text { Squares }\end{array}$ & $\mathrm{df}$ & $\begin{array}{c}\text { Mean } \\
\text { Square }\end{array}$ & $\mathrm{F}$ & Sig. \\
\hline \multirow[t]{3}{*}{1} & Regression & 330.915 & 2 & 165.457 & \multirow[t]{3}{*}{32.915} & \multirow[t]{3}{*}{, $000^{b}$} \\
\hline & Residual & 487.595 & 97 & 5.027 & & \\
\hline & Total & 818.510 & 99 & & & \\
\hline
\end{tabular}

actual total score of 2210 , the ideal total score of 2500 percent of the values of $88 \%$, fits very well in the category. This shows that the product innovation of Bluebutton fashion products is already very good. Product innovation variables include (1) line extensions, (2) metoo products, and (3) newtotheworld products.

\section{Influencer marketing in Bluebutton}

The results showed that in the influencer marketing variable (X2) got the actual total score value of 2612, the ideal total score of 3000 percent values of $87 \%$, fits very well in the category. This proves that the influencer marketing shown by Bluebutton's fashion products is already very good. The variables of influencer marketing consist of (1) Interested in finding information about the product, (2) Wanting to know the product, (3) Interested in trying, (4) Considering to buy, and (5) You want to have a product.

\section{Buy Interest in Bluebutton}

The results showed that in the variable Purchase Interest $(\mathrm{Y})$ got the value of the actual total score of 2157 , the ideal total score of 2500 percent values of $86 \%$, s 'fits very well in the 
category. This shows that the buying interest in Bluebutton fashion products is already very good. Buying interest variables consist of (1) Attractiveness, (2) Trustworthiness, and (3) Expertise.

\section{Summary}

Based on the results of previous research and discussions, the following conclusions were drawn:

1. Regarding the test results, $\mathrm{F}$ indicates that the variable buying interest $(\mathrm{Y})$ of Bluebotton fashion products will be 32,915 points and this figure has not been influenced by the Variables (X1) Product innovation and influencer marketing (X2). However, the number was influenced by other variables outside of the study.

2. A value of 0.636 was obtained from the results of the correlation coefficient test $(\mathrm{R})$, so that it can be concluded that the relationship between the product innovation variables (X1) and influencer marketing (X2) is strongly related to the purchase rate variable (Y), which is 63,6 $\%$.

3. The results of the investigation give a value of 0.404 for the coefficient of determination (R2), which shows that the contribution of the product innovation variables (X1) and influencer marketing (X2) to the buying interest (Y) in the remaining $40.4 \%$ of the remaining $59,6 \%$ influenced by other variables not included in the study.

4. The product innovation variable (X1) has a regression coefficient of 0.110 and the influencer marketing variable (X2) has a regression value coefficient of 0.617. From this it can be concluded that if the company offers a good product innovation (X1) and influencer marketing (X2) the customer's interest in buying (Y) increases.

\section{Refferences}

[1] Agus, R. d. (2019). Pengaruh Inovasi Produk Terhadap Keputusan Pembelian Konsumen. Jurnal Strategic, 1-20.

[2] Alexander, W. (2018). Pengaruh Influencer Marketing Sebagai Strategi Pemasaran Digital Era Moderen. Jurnal Eksekutif, 15, 1.

[3] Armstrong, P. K. (2017). Principles of Marketing. New Jersey: Prentice Hall.

[4] Biaudet, S. (2017). Influencer Marketing as a Marketing Tool (The process of creating an Influencer Marketing Campaign on Instagram). International Business, 109-121.

[5] Cynthiadewi, P. R. (2018). The Influence of Electronic Word of Mouth Toward Brand Image and Purchase Intention of 13th Shoes. . International Journal Conference on Economics, 10-18.

[6] Dheanda, M. C. (2020). Pengaruh Influencer Terhadap Purchase Intention Produk Pixy Melalui Source Characteristics (Studi Pada Beauty Vlogger Tasya Farasya). Universitas Telkom, 101-120.

[7] Gunawan, A. D. (2016). The Effect on Involvement and Electronic Word of Mouth (eWOM) on Brand Image and Its Impact on Consumers Brnd Switching of Mamypoko. International Journal of Economic and Maagement, 19-31. 


\section{Technium Sustainability}

[8] Husein, U. (2016). Riset Pemasaran dan Perilaku Konsumen. Jakarta: Pustaka Utama.

[9] Kanuk, S. \&. (2018). Consumer Behaviour 7th Edition. Jakarta: PT.Indeks .

[10] Kotler, P. (2019). Manajemen Pemasaran. Jakarta: PT. Indeks.

[11] Pavlou, P. A. (2018). Consumer Acceptance of Electronic Commerce: Integrating Trust and Risk with the Thecnology acceptance Model. International Journal of Electronic Commerce, 69-103.

[12] Prahardjo, A. W. (2016). The Impact of Electronic Word of Mouth on Repurchase Intention Mediated by Brand Loyalty and Perceived. South East Asia Journal of Contempory Business, 2289-1560.

[13] Ranjbarian, B. S. (2017). An Analysis of Brand Image, Perceived Quality, Customer Satisfaction and Re-Purchase Intention in Iranian Departemen Stores. International Journal of Economic and Maagement, 40-48.

[14] Sari, F. P. (2016). Pengaruh Harga, Citra Merek dan Word of Mouth terhadap Keputusan Pembelian Konsumen. Jurnal Ilmu dan Riset Manajemen, 16-20 .

[15] Sugiharto. (2018). Pengaruh Kredibilitas Influencer terhadap Sikap pada Merek. Jurnal Strategi Pemasaran, 97-110.

[16] Sugiyono. (2017). Metode Penelitian Kuantitatif, Kualitatif, dan R \& D. Bandung: CV Alfabeta 